\title{
ЕВРАЗИЙСКИЕ ПЕРЕКРЕСТКИ
}

\author{
И. Г. ЧУБАРОВ \\ Пять составляющих внешнеэкономического \\ курса Китая «Один пояс, один путь» *
}

\author{
Илья Георгиевич Чубаров, канд. геогр. наук, \\ ст. науч. сотр. Института Дальнего Востока РАН. \\ E-mail: ilya.chubarov@gmail.com
}

\begin{abstract}
Аннотация. В Аанной статье предпринята попытка выйти за рамки распространенного представления о китайской стратегии «ОАин пояс, один путь» (ОПОП) как наборе евроазиатских логистических коридоров и привязанных к ним инвестиционных и транспортных проектов. Анализ содержания пяти вы винутых «интеграционных направлений» (внешнеполитического, инорраструктурного, торгово-экономического, фринансового и гуманитарного) и практики работы китайского правительства показывает, что ОПОП представляет собой комплекс разнородных мероприятий по сопровождению выхода китайских коммерческих фрирм на милируюшие позиции в самых разных отраслях мировой экономики. Продвижение «национальных чемпионов» вверх по цепочкам Аобавленной стоимости является необходимым условием закрепления Китая в я ре мирового хозяйства. Арена хействий - страны периферии и полупериорерии («страны пояса и пути»), гАе Китай в рамках ОПОП постепенно теснит корпорации развитых

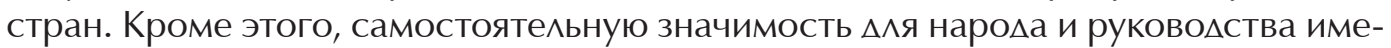
ет укрепление статуса Китая в глазах межлународного сообшества и фрормирование имиджа великой державы. Рассмотрение ОПОП как следующего, закономерного этапа политики внешнеэкономической открытости Китая на новом витке глобализации и одновременно самоценного инструмента восстановления престижа страны на мировой арене позволяет более точно определить целеполагание китайской стороны при реализации совместных проектов.
\end{abstract}

КАючевые слова: Китай, «ОАин пояс, один путь», глобализация.

Китайский народ, вооруженный всеми производительными силами, необходимыми для дальнейшего внутреннего развития своей страны, может отвернуться от своих ицвилизаторов: выбившись из-под промышленной опеки, он вытеснит их со своего рынка, захватит в свои руки зарубежные рынки и возьмет на себя задачу развития отстающих частей земного шара.

Джон Гобсон. Империализм (1902 г.)

В 2018 г. Китай отмечает 40 лет с начала реформ и открытости, в ходе которых произошел относительно безболезненный переход от плановой системы советского образца к регулируемой многоукладной рыночной модели смешанного типа. Претворение в жизнь градуалистских рыночно-ориентированных реформ привело к существенному повышению уровня жизни всего населения и формированию мощнейшей производственной базы, что можно считать основными критериями успеха. Несмотря на признание в 2013 г. решающей роли

\footnotetext{
* Исследование проведено в рамках гранта Президента РФ по государственной поддержке молодых ученых - кандидатов наук № MK-2007.2017.6.
} 
рынка, важнейшей характеристикой «китайской модели» было и остается сохранение государственного планирования и сильные позиции госсобственности во многих отраслях (подробнее о китайской модели и ходе реформ см.: [1; 2; 7]). Исходя из этого, закономерности отраслевого и территориального развития Китая невозможно выявить, опираясь исключительно на анализ рыночных факторов конкурентоспособности, без учета государственной политики и механизмов её реализации [23].

Аналогичная конфигурация в последние годы отчетливо вырисовывается и во внешнеэкономической деятельности. Стремительное увеличение объема внешних связей Китая демонстрирует признаки перехода в новое качество. Если в первые десятилетия реформ усилия правительства были почти полностью сосредоточены на привлечении в страну иностранных инвестиций, то в последние годы, в связи с концентрацией капитала внутри страны и закономерным увеличением китайского коммерческого присутствия за рубежом, административное руководство всех уровней всё больше внимания уделяет содействию заграничной деятельности местных фирм.

Руководство Китая ещё в начале 1990-х гг. начало обсуждать выход китайских фирм на зарубежные рынки, а оформленный вид и название «выход вовне» (изоу чу цюй) этот курс приобрел в середине 2000-х гг. В то время казалось, что инициатива явно опережала реальные возможности и потребности, но за прошедшие годы вынос производства за границу получил солидную экономическую основу. «Национальные чемпионы» (лунтоу иц'е - дословно, «голова дракона») - крупные китайские производственные, строительно-подрядные и финансовые корпорации, как государственные, так и частные, - за счет работы на внутреннем рынке накопили значительный объем средств и достигли технологического и управленческого уровня, позволившего начать самостоятельную работу на иностранных рынках. Рост оплаты труда, сокращение численности трудоспособного населения, повышение себестоимости производства, насыщение рынка госзаказа в сфере инфраструктуры в Китае создали условия не просто для экспорта товаров, а для переноса за рубеж части или всей экспортно-ориентированной производственной цепочки.

Стратегической реакцией на появление новых возможностей стала предложенная Китаем в 2013 г. инициатива «Один пояс, один путь» (ОПОП, англ. Belt and Road Initiative, BRI). В 2017 г. положение о создании ОПОП вошло в устав правящей партии. В зарубежной прессе и профессиональном сообществе распространено понимание ОПОП как транспортно-логистической программы строительства связывающих государства Евразии торговых путей и интегрированных с ними инвестиционных проектов. Такой акцент обусловлен рядом факторов - прежде всего, широко растиражированными технологическими успехами Китая в этой области, а также выбранным названием с отсылкой к транспортным путям. Немаловажно и словоупотребление: китайский глагол изяньшэ, используемый в официальных документах по ОПОП, обычно дословно переводится как «строить», в то время как в контексте обсуждения государственной программы больше подходит другое значение - «создавать», «созидать», «формировать». Однако цели международного курса Китая явно шире - на официальном уровне говорится о «великом возрождении китайской нации» и «движении к центру мировой сцены» ${ }^{1}$ Поэтому и многие эксперты приходят к выводу, что «прокладка транспортных артерий не является главной целью [ОПОП]» [11, с. 6].

После первого упоминания ОПОП в 2013 г. основные положения и формулировки «шлифовались» около пяти лет и были опубликованы двумя официальными изданиями [14; 16]. Представление о практике ОПОП можно получить из опубликованных в мае 2017 г. «Списка достижений ОПОП» ${ }^{2}$ и совместного коммюнике Форума «Пояса и пути» ${ }^{3}$, материалов официального сайта «Один пояс, один путь» (https://www.yidaiyilu.gov.cn/, ведется Канцелярией малой руководящей группы по делам ОПОП), крупномасштабного 6-серийного документального фильма центрального телевидения «Пояс и путь» $(2016)^{4}$, телепрограммы «Расшифровывая ОПОП» (2016-

\footnotetext{
${ }^{1}$ China Moving Closer to Global Center Stage in the New Era // China Today, Vol. 66, No. 12, December 2017.

2 «И дай и лу» гоцзи хэцзо гаофэн луньтань чэнго циндань (цюянь вэнь) [Список результатов международного Форума «Один пояс, один путь»] // Официальный сайт МИД KHP. - 2017. 16 мая - URL: http://www.fmprc.gov.cn/web/zyxw/ t1461873.shtml

${ }^{3}$ Совместное коммюнике по итогам круглого стола лидеров в рамках международного Форума «Один пояс, один путь» // Официальный сайт Президента РФ. - 2017. 15 мая - URL: http://www.kremlin.ru/supplement/5188

${ }^{4}$ И дай и лу (The Belt and Road) // Сайт онлайн-кинотеатра iQiyi. - URL: http://www.iqiyi.com/a_19rrh9qrm9.html
} 
2018 гг. $)^{5}$, документального кинофильма «Великолепный Китай» $(2018 \text { г. })^{6}$, данных с регулярных мероприятий Пресс-канцелярии Госсовета КНР, в том числе пресс-конференции в честь 5-летия ОПОП в 2018 г.7, выступлений китайских руководителей на различных площадках и др.

Каркасом ОПОП, согласно этим материалам, являются «Пять интеграционных направлений» $($ у тун):

- внешнеполитическое (чжэнцэ гоутун, дословно «координация политических курСOB»);

- инфраструктурное (шэши ляньтун, «взаимосвязь инфраструктуры»);

- торгово-инвестиционное (маои чантун, «бесперебойная торговля»);

- финансовое (цзыцзинь жунтун, «свободное передвижение капитала»);

- гуманитарное, или «мягкая сила» (миньсинь сянтун, «укрепление близости народов»).

Объектом ОПОП являются «страны пояса и пути» (яньсянь гоизя), в число которых, согласно различным официальным и экспертным источникам, входят от 40 до 60 и более стран Азии, Африки и Восточной Европы. В последнее время «страны “Пояса и пути”» в расширенном виде трактуются как весь развивающийся мир, что позволяет рассматривать их как периферию и полупериферию мирового хозяйства целиком, без жесткой географической привязки [19].

\section{ТОРГОВО-ИНВЕСТИЦИОННОЕ НАПРАВАЕНИЕ}

Торгово-инвестиционное направление ОПОП является стержнем всей стратегии и представляет собой комплекс мер по активизации и поддержке самостоятельных торговых, инвестиционных и производственных проектов китайских компаний за рубежом.

Согласно данным ЮНКТАД (World Investment Report 2018), за 2000-2017 гг. доля КНР в мировых накопленных ПИИ выросла с 0,4 до 4,8 \%, а их общий объем превысил 1,4 трлн долл. (без Гонконга). По оценкам, за 2015-2020 гг. они вырастут еще как минимум на 500 млрд долл. ${ }^{8}$, а объем иностранных активов под китайским контролем возрастет с нынешних 6,5 до 20 трлн долл. 9 Выделяют четыре основных направления инвестирования Китая за рубеж: получение доступа к современным технологиям (покупка существующих фирм), к сырьевым ресурсам (разработка месторождений), к дешевой рабочей силе (перенос трудоемких производственных звеньев) и к местному рынку (создание сбытовых и сервисных подразделений) [15].

Используя свои конкурентные преимущества (в первую очередь капитал и технологии), Китай руками частных и государственных компаний постепенно разворачивает индустриализацию менее развитых регионов мира. Быстрее всего этот процесс идет в Юго-Восточной Азии, Африке и Пакистане. Дешевая рабочая сила и хорошие политические отношения создают условия для переноса туда трудоемких производств, малорентабельных в самом Китае. К примеру, среди африканских стран лидером в привлечении китайских производственных инвестиций является Эфиопия, где эксперты насчитывают более 400 реализованных китайских промышленных проектов. Примером поощряемой Китаем модели является шэньчжэньская компания «Чуань Инь» (Transsion). Компания производит мобильные телефоны под брендами Itel и Tecno, за последние пять лет они были выведены на лидирующее место на африканском рынке (38 \% в 2016 г.). В 2011 г. компания локализовала производство в Эфиопии и готовит к открытию вторую фабрику в Нигерии. Общее число местных сотрудников превышает 4 тыс. ${ }^{10}$

Получила широкое распространение модель «совместного выхода» за границу нескольких

\footnotetext{
${ }_{5}^{5}$ Цзема и дай и лу (Decoding the BRI) // Сайт онлайн-кинотеатра iQiyi. - URL: http://www.iqiyi.com/a_19rrham315.html

${ }^{6}$ Лихай лэ, во дэ го (Amazing China) // Сайт онлайн-кинотеатра iQiyi. - URL: http://www.iqiyi.com/lib/m_216901214.htm

${ }^{7}$ URL: Госиньбань цзюйсин гунцзянь «И дай и лу» 5 нянь цзиньчжань цинкуан цзи чжаньван фабухуй [Пресс-канцелярия Госсовета провела пресс-конференцию, посвященную развитию за 5 лет и дальнейшим перспективам совместного построения ОПОП] // Официальный сайт Госсовета KHP. 27.08.2018. - URL: http://www.scio.gov.cn/xwfbh/xwbfbh/ wqfbh/37601/38866/wz38868/Document/1636162/1636162.htm

${ }^{8}$ Chinese President's Speech at Boao Forum for Asia // Синьхуаван [Интернет-сайт ИА «Синьхуа»]. - 2015. 28 марта - URL: http://news.xinhuanet.com/english/2015-03/29/c_134106145.htm

${ }^{9}$ China to Become One of World's Biggest Overseas Investors by 2020 // Financial Times, June 26, 2015. - URL: https://www.ft.com/ content/5136953a-1b3d-11e5-8201-cbdb03d71480

${ }^{10}$ Transsion, the King of Mobile Phone in Africa Makes a Fortune in Low-profile // Pandaily, October 19, 2017. - URL: https:// pandaily.com/transsion-king-mobile-phone-africa-makes-fortune-low-profile/
} 
предприятий-смежников через создание промышленного парка. Совместный промпарк обладает рядом преимуществ: государственное финансирование, официальный межгосударственный статус (внимание со стороны принимающих властей и льготный административный режим), экономия за счет коллективного пользования сопутствующей инфраструктурой (гостиницы, конференц-залы, переводческие, юридические, бухгалтерские услуги, найм персонала и т. п.). Есть выгоды и для принимающей стороны - «одно окно» для общения с китайскими предприятиями и возможность воздействия по межгосударственным каналам. В отдельных случаях китайские предприятия в промпарках ради снижения конкуренции с местными производствами и купирования социальной напряженности работают только на экспорт. За пять лет с начала ОПОП Китаем за рубежом было создано 82 таких парка, в которых разместилось почти 4 тыс. предприятий. За время своей работы они уплатили в казну принимающих стран 2 млрд долл. налогов и создали 244 тыс. рабочих мест.

Важным, но относительно малоизвестным механизмом содействия продвижению китайских предприятий за рубеж является государственная Китайская экспортно-кредитная страховая корпорация (Sinosure). По данным на конец 2017 г., за годы своей деятельности (создана в 2001 г.) Sinosure застраховала торговые и инвестиционные операции 110 тыс. китайских компаний общей суммой более 3,3 трлн долл. США и выплатила им 11 млрд долл. компенсаций по страховым случаям ${ }^{11}$. Корпорация не получает операционной прибыли, но при сопровождении сделок специалисты Sinosure накапливают уникальный по объему опыт работы на зарубежных рынках. Это позволяет оказывать квалифицированную аналитическую, правовую и консультационную поддержку обращающимся клиентам (например, по работе с иностранным госзаказом), многие из которых не имеют опыта работы за рубежом. За годы работы специалисты Sinosure сопроводили более 1000 инвестиционных проектов китайских фирм в 62 странах, на основании чего издают ежегодный справочник зарубежных коммерческих рисков.

Китайское правительство не только стимулирует иностранные инвестиции своих фирм. Несколько неудачных примеров наглядно продемонстрировали не всегда удовлетворительный уровень компетенций китайских предпринимателей при ведении бизнеса за границей и их способности ответственно распорядиться заработанным на внутреннем рынке капиталом. Одним из наиболее показательным можно считать пример компании «Лэ Ши» («LeEco»). Начав в 2004 г. с успешного на внутреннем рынке онлайн-кинотеатра, через 10 лет компания попыталась одновременно выйти на американский и европейский рынки смартфонов, а также запустила проекты в ряде других популярных отраслей. Однако потраченные инвестиции не принесли результата, закрепиться на иностранных рынках не удалось, в результате фирма оказалась на грани банкротства. Начиная с 2016 г. китайское правительство значительно ужесточило контроль исходящих инвестиций в ряде отраслей.

Слабым местом Китая являются торговые марки (бренды). Благодаря формированию устойчивых символических ассоциаций и неформальных репутационных привязанностей бренд повышает лояльность клиентов и позволяет повысить прибыльность реализации аналогичной продукции. Стоимость бренда зачастую не привязана к товару, а отражает его известность и уровень доверия потребителей и профессионального сообщества. Большое число всемирно известных брендов - одно из важных экономических преимуществ развитых стран.

В Китае относительная закрытость внутреннего рынка позволила сформироваться большому числу успешных брендов почти в каждой товарной или сервисной группе. Однако за исключением фирм «Леново» и «Хуавэй», занимающих, соответственно, 100 -е и 70 -е места в рейтинге самых дорогих брендов, остальные китайские торговые марки малоизвестны за рубежом ${ }^{12}$. Международным китайским компаниям мешает отсутствие глобальной маркетинговой стратегии, погоня за краткосрочными интересами, недостаток собственных квалифицированных кадров и понимания у топ-менеджмента значимости выстраивания бренда ${ }^{13}$. Негативную роль играет и слабая защита интеллектуальной собственности на внутреннем рынке.

Чтобы догнать лидеров, китайские компании развивают собственные бренды и покупают уже существующие. В рамках ОПОП Китай прикладывает усилия для формирования глобального маркетингового охвата «национальных чемпионов». Как одну из мер в этом направлении

\footnotetext{
${ }^{11}$ Corporate Profile. Официальный сайт “China Export and Credit Insurance Corporation”. - URL: http://www.sinosure.com.cn/ en/Sinosure/Profile/index.shtml

${ }^{12}$ Best Global Brands 2017 Rankings // Interband. - URL: http://interbrand.com/best-brands/best-global-brands/2017/ranking/

${ }^{13}$ What Chinese Brands Must Do to Go Global // China Daily, May 17, 2018. - URL: http://www.chinadaily.com.cn/a/201805/17/ WS5afce3bfa3103f6866ee8fld.html
} 
Центральное телевидение в конце 2016 г. запустило на общенациональном уровне проект «Национальная программа торговых марок» (гоизя пиньпай изихуа). Были отобраны 45 лидирующих компаний различных потребительских отраслей. При помощи своих медийных ресурсов ЦТ популяризирует их бренды и помогает выстраивать маркетинговую стратегию за рубежом. С 2017 г. ежегодно проводится национальный «День бренда», призванный повысить грамотность предпринимателей в этом аспекте ведения бизнеса. К нему приурочена выставка китайских брендов в Шанхае (впервые состоялась в мае 2018 г.).

Растущая международная активность китайских компаний закономерно подтверждается статистикой заявок на регистрацию торговых марок. По данным агентства CompuMark, в период 2012- 2017 гг. число заявок на регистрацию торговых марок, поданных китайскими компаниями в остальных странах мира, выросло с 40 до 120 тыс. Три главных региона, где китайские компании стремятся зарегистрировать свои торговые марки, - Северная Америка, Европа и крупные соседние страны (Япония, Корея, Индия, Малайзия, Таиланд). 30 \% всех заявок составляют торговые марки в сфере электроники и телекоммуникаций, $25 \%$ - одежда, обувь и бижутерия, $20 \%$ - бытовая техника и инструменты [21]. Показательно, что это те отрасли, в которых китайская продукция доминирует на мировом рынке и созрели предпосылки формирования глобальных брендов.

Помимо развития своих брендов, китайские компании при содействии государства (переговорная поддержка, льготные кредиты и др.) приобретают уже состоявшиеся зарубежные бренды (cм. Табл.). Наиболее показательными сделками стали покупка компанией «Леново» американских брендов IBM (2005 г., 1,8 млрд долл.) и Motorola (2014 г., 2,9 млрд долл.), компанией «Хайер» - бренда General Electric Appliances (2016 г., 5,4 млрд долл.), компанией «Цзили» - бренда Volvo (2010 г., 1,3 млрд долл.), компанией «Шуанхуэй» - бренда Smithfield (2013 г., 4,7 млрд долл.), компанией ChemChina - бренда Pirelli (2016 г., 7,6 млрд долл.). Китайские компании покупают бренды своих прямых конкурентов и в дальнейшем развивают их с привлечением собственных ресурсов.

Таблица

Крупнейшие сделки по покупке зарубежных компаний и брендов

\begin{tabular}{|l|l|l|c|c|}
\hline \multicolumn{1}{|c|}{$\begin{array}{c}\text { Компания и страна } \\
\text { происхождения }\end{array}$} & \multicolumn{1}{|c|}{ Отрасль } & \multicolumn{1}{|l|}{ Покупатель } & $\begin{array}{c}\text { Стоимость, млрд } \\
\text { долл. США }\end{array}$ & Год приобретения \\
\hline Pirelli (Италия) & Автошины & ChemChina & 7,6 & 2016 \\
\hline $\begin{array}{l}\text { General Electric } \\
\text { Appliances (США) }\end{array}$ & Бытовая техника & Haier & 5,4 & 2016 \\
\hline KUКА (Германия) & $\begin{array}{l}\text { Промышленные } \\
\text { роботы }\end{array}$ & Midea & 5,1 & 2016 \\
\hline Smithfield (США) & Мясные продукты & Shuanghui & 4,7 & 2013 \\
\hline Motorola (США) & $\begin{array}{l}\text { Мобильные } \\
\text { телефоны }\end{array}$ & Lenovo & 2,9 & 2010 \\
\hline Volvo (Швеция) & Автомобили & Geely & 1,3 & 2005 \\
\hline IВМ (США) & ПК & Lenovo & 1,8 & 2016 \\
\hline Tозһiba (Япония) & Бытовая техника & Midea & 0,5 & \\
\hline
\end{tabular}

Составлено автором по данным СМИ.

\section{«ФИНАНСОВАЯ ИНТЕГРАЦИЯ»}

Облегчить китайскому капиталу проникновение на зарубежные рынки призвана «финансовая интеграция» ОПОП. Для полноценного участия в мирохозяйственных связях Китай стремится к изменению глобальной валютно-финансовой инфраструктуры. Эксперты, в частности, отмечают, что «занятие доминантных позиций в многосторонних банках развития открывает широкие возможности реализовывать национальные интересы» [10, с. 81]. В силу этого Китай последовательно выступает за увеличение квоты развивающихся стран в международных финансовых организациях, которые в настоящее время контролируются субъектами центра мирового хозяйства. Доля КНР в мировой экономике уже превысила $15 \%$, однако даже после 
последних раундов пересчета доля его голосов в МВФ составляет лишь 6,41 \%, а во Всемирном банке $-4,57 \%$, что меньше, чем у США и Японии.

Столкнувшись в последние годы с нежеланием поделиться контролем за системообразующими финансовыми институтами, Китай создал новые каналы международного финансирования - Азиатский банк инфраструктурных инвестиций (АБИИ) со штаб-квартирой в Пекине (уставный капитал 100 млрд долл., доля КНР 26,6 \%) и Новый банк развития (НБР) со штаб-квартирой в Шанхае (уставный капитал 50 млрд, доля КНР 20 \%). Их деятельность призвана оказать давление на традиционные многосторонние банки развития в направлении реформирования структуры управления, операционных правил и инвестиционных приоритетов [10]. Находящиеся под контролем КНР международные финансовые институты мультиплицируют имеющиеся в ее распоряжении финансовые рычаги. На один вложенный Китаем доллар другие участники добавляют ещё 3-4, при этом по отдельности их вес мал, что оставляет право итогового решения Китаю. Объем проинвестированных АБИИ средств по данным на середину 2018 г. составил 5,2 млрд, НБР - 4,9 млрд долл. США.

Помимо многосторонних финансовых институтов, Китай создает совместные инвестиционные фонды для работы с отдельными странами. Например, Российско-китайский инвестиционный фонд распоряжается капиталом в 2 млрд долл. в равных доля от РФ и КНР, китайско-бразильский фонд - 20 млрд (доля КНР - 75 \%), совместный фонд с ОАЭ - 10 млрд и т. д. В эту же категорию можно отнести созданные в 2007 г. Китайско-африканский фонд развития и в 2015 г. Китайско-африканский фонд промышленного сотрудничества (оба с капиталом 10 млрд долл. и долей КНР в 100 \%). По ряду оценок объем капитала, который Китай реализует на внешних рынках через свои институты развития (Государственный банк развития и Экспортно-импортный банк Китая), уже превысил аналогичные показатели МВФ и Всемирного банка. ${ }^{14}$

Параллельно с развитием альтернативных каналов международного финансирования Китай прилагает усилия для интернационализации юаня. Помимо очевидной имиджевой составляющей, основная цель заключается в устранении сложностей реализации зарубежных проектов, связанных с выводом полученных в местной валюте средств, потерями на колебаниях обменного курса (наиболее актуально для долгосрочных проектов в слаборазвитых странах) и трудностями с получением займов на китайском финансовом рынке под залог иностранных активов. Для этого Китай, опираясь на большой объем накопленных валютных резервов, активно продвигает использование юаней на финансируемых зарубежных проектах, выпускает юаневые займы с выгодной ставкой и прикладывает усилия по переводу на юани деятельности совместных индустриальных парков за рубежом. Для облегчения кредитования в юанях иностранными банками Китай расширяет охват валютных свопов и число клиринговых центров. В 2015 г. была запущена межбанковская платежная систему CIPS (Cross-Border Interbank Payment System), в которой участвуют 11 иностранных банков (в их числе российский ВТБ).

Успехом на этом направлении стало включение в 2016 г. китайского юаня в корзину специальных прав заимствования МВФ (вес - 10,92 \%), что стало подтверждением его значимой роли и свободного обращения в международной торговле. Тем не менее доля юаня в структуре международных платежей и резервов пока не превышает 2-3\%. Другим свидетельством усиления роли Китая в мировой финансовой системе является развитие платежных систем UnionPay, AliPay и WeChatPay как альтернативы Visa и MasterCard в развивающихся странах ${ }^{15}$, создание международных рейтинговых агентств (в частности, Chengxin Credit Ratings, Lianhe Credit Rating и Dagong Global Credit) и выход китайских банков за рубеж. По данным на середину 2018 г., в общей сложности 11 банков с китайским капиталом открыли за рубежом 71 филиал.

Приведенные факты свидетельствуют, что в рамках ОПОП Пекин ведет курс на выстраивание китаецентричной системы международных правил, норм и институтов [9]. Путем предоставления «странам “Пояса и пути”» альтернативно развитым странам и контролируемым ими международным институтам целевого и политического финансирования Китай создает условия для успешного выхода своих частных и государственных компаний на зарубежные рынки.

\footnotetext{
${ }^{14}$ China's Growing Clout in International Economic Affairs // The Economist, March 23, 2017. - URL: https://www.economist. com/finance-and-economics/2017/03/23/chinas-growing-clout-in-international-economic-affairs

${ }^{15}$ China's Fight with Visa and MasterCard Goes Global // Financial Times, April 24, 2017. - URL: https://www.ft.com/content/ a67350fa-1f6f-11e7-a454-ab04428977f9
} 


\section{ВНЕШНЕПОАИТИЧЕСКОЕ НАПРАВАЕНИЕ}

Внешнеполитическое направление призвано поддерживать зарубежные китайские коммерческие проекты с помощью межправительственных и дипломатических механизмов. Крупнейшим мероприятием стал пекинский Форум «Пояса и пути» в 2017 г., в котором приняли участие представители 130 стран и 70 международных организаций. На двусторонней основе Китай к середине 2018 г. заключил 118 соглашений в рамках ОПОП с 103 государствами и международными организациями, в том числе с Россией (ЕАЭС).

Одной из главных задач является борьба с протекционизмом. В знаковом выступлении на экономическом форуме в Давосе в 2017 г. Си Цзиньпин охарактеризовал ОПОП как «китайский способ защитить открытость мировой экономики» ${ }^{16}$. Общепризнано, что Китай является одним из главных выгодоприобретателей современного этапа экономической глобализации, он «успешно приспособился к американской модели глобализации и не заинтересован в дроблении и кластеризации единого мирового рынка» [17, с. 21]. К настоящему времени Китай имеет соглашения о свободной торговле с 24 странами (Австралия, Республика Корея, Швейцария, Исландия, Коста-Рика, Перу, Сингапур, Чили, Пакистан, Грузия, Мальдивы и 10 стран АСЕАН), из них 13 заключены за последние 5 лет. Вкладу Китая в либерализацию международного торгово-инвестиционного режима посвящена опубликованная пресс-канцелярией Госсовета КНР «белая книга» «Китай и ВТО» ${ }^{17}$. При этом доступ иностранных компаний на внутренний рынок Китая по-прежнему затруднителен. В ответ на связанные с этим недовольства зарубежных партнеров в середине 2018 г. Китай объявил о наращивании импорта, в рамках чего среди прочего организована первая Китайская международная ярмарка импорта (ноябрь 2018 г.) $)^{18}$.

Борясь с протекционизмом, в начале 2018 г. Китай выдвинул идею создать международные арбитражные центры на своей территории. На первом этапе объявлено о создании двух «международных коммерческих судов», которые будут располагаться в Шэньчжэне и Сиане. Международный арбитраж открылся в 2018 г. в Хайкоу (пров. Хайнань). Такой подход несет потенциал коренной трансформации международной правовой системы, основой которой в настоящее являются английский язык и западные правовые нормы.

Принципиальной чертой политической координации в рамках ОПОП является отсутствие требований политико-идеологического характера. В отличие от западных стран, китайское руководство считает, что каждая страна имеет право на подходящую местным условиям общественную модель ${ }^{19}$. Избегая прямой критики, в качестве альтернативы «универсальным демократическим ценностям» Китай продвигает более мягкие идеи об «инклюзивной глобализации» (баожунсин цюаньцюхуа, см. [12]) и человечестве как «сообществе общей судьбы» (минюнь гунтунти). Среди всех прав человека Китай акцентирует право на развитие и улучшение материальных условий жизни ${ }^{20}$.

В дополнение к двусторонним и многосторонним форматам, под эгидой ОПОП Китаем выдвинута концепция шести «экономических коридоров Шелкового пути», каждый из которых по географическому признаку объединяет несколько приграничных стран и макрорегионов. Сопоставление планов развития западных и северо-восточных регионов КНР свидетельствует, что по своей пространственной конфигурации предлагаемые в рамках «Пояса и пути» международные коридоры являются выдвинутым за рубеж продолжениями осей территориального развития приграничных регионов Китая. «Коридоры ОПОП» в этом контексте являются «интерфейсом» доступа к территориальному и отраслевому планированию приграничных стран и регионов для поддержки вариантов, наиболее способствующих развитию Китая (подробнее см. [18]).

\footnotetext{
${ }^{16}$ Economic Watch: Boao Forum to Rally Support for Globalization // Синьхуаван [Интернет-сайт ИА «Синьхуа»]. - 2017. 24 марта. - URL: http://news.xinhuanet.com/english/2017-03/23/c_136152630.htm

17 Чжунго юй Шиизе маои изучжи [Китай и ВTO] // Официальный сайт Госсовета KHP. - 2018. 28 июня - URL: http://www. gov.cn/zhengce/2018-06/28/content_5301884.htm

${ }^{18}$ Гуан юй кода изинькоу иузцинь дуйвай маои пинхэн фачань дэ иизянь [Мнение по поводу увеличения импорта и стимулирования сбалансированной внешней торговли] // Канцелярия Госсовета КНР. Го Бань Фа. (2018) № 53 от 02.07.2018. -URL: http://www.gov.cn/zhengce/content/2018-07/09/content_5304986.htm

${ }^{19}$ China Rejects Claim It Wants to Change Global Order // China Daily, March 4, 2018. - URL: http://www.chinadaily.com. cn/a/201803/04/WS5a9b8171a3106e7dcc13f686.html)

${ }^{20}$ South-South Human Rights Forum Calls for Protection of People's Right to Development // China Daily, December 8, 2017. URL: http://www.chinadaily.com.cn/a/201712/08/WS5a2a8f63a310eefe3e99ef75.html)
} 
В координации ОПОП активно задействованы межрегиональные связи: выходящим к госгранице китайским провинциям вменяется наращивать частоту обменов и свои компетенции в отношении соседних стран. Одновременно стимулируется использование трансграничного потенциала для повышения уровня жизни в периферийных регионах Китая. Естественный процесс трансграничных коммуникаций в рамках ОПОП проходит дополнительную институционализацию. К примеру, в Гуанси-Чжуанском автономном районе ежегодно проводится выставка «Китай - АСЕАН», во Внутренней Монголии выставка «Китай - Монголия», в Хэйлунцзяне - Российско-китайское ЭКСПО.

В силу исторических факторов китайцы придают повышенное значение статусу своей страны в мире («возрождение после столетия унижений») и выстраиванию образа «ответственной глобальной державы» (подробнее см. [13]). В силу этого широкое освещение в СМИ получают даже самые общие соглашения в рамках ОПОП, которые подаются как укрепление международных позиций страны.

\section{ИНФРАСТРУКТУРНОЕ НАПРАВАЕНИЕ}

Транспорт и инфраструктурное направление являются наиболее обсуждаемой в СМИ стороной ОПОП. Накопив в ходе модернизации инфраструктуры внутри страны опыт и технологии, китайские строительные компании в последние годы успешно борются за подряды на строительство большого числа объектов за рубежом. При этом «модернизация инфраструктуры» в китайской трактовке включает в себя не только транспорт, но также и все другие объекты, которые необходимы для функционирования общества и во многих странах находятся на государственном балансе - электросети, подстанции мобильной связи, больничные, учебные и научные корпуса, административные здания, культурные и музейные центры. При таком подходе потенциальный зарубежный рынок инфраструктурных заказов увеличивается многократно.

В области транспортной инфраструктуры компоненты китайского курса включают в себя строительство новых и модернизацию старых путей автомобильного и железнодорожного сообщения между Европой и Китаем, а также общее увеличение транспортной связности между странами Евразии [24]. Для развития международных железнодорожных грузовых перевозок в 2011 г. был создан зонтичный бренд China Railway Express (Чжуноу баньле). Государство субсидирует такие товарные поезда, выделяет для них лучшие локомотивы и приоритетные временные слоты. С 2011 по август 2018 г. был отправлено 10 тыс. подобных международных товарных составов, прямое железнодорожное сообщение связало Китай с 43 городами 15 европейских стран. К 2020 г. планируется довести число товарных составов до 5 тыс. ежегодно ${ }^{21}$.

Обращает на себя внимание «дипломатия» скоростных железных дорог. Благодаря успешной локализации зарубежных технологий и государственной поддержке китайские фирмы добились значительного прогресса в технологиях строительства высокоскоростных железнодорожных магистралей (ВСМ). За последнее десятилетие в стране была построена самая крупная в мире сеть ВСМ, составляющая более 20 тыс. км. Успешный опыт позволяет китайским компаниям браться за зарубежные проекты ВСМ и обычных железнодорожных линий (на разных стадиях находятся линии Момбаса - Найроби, Аддис-Абеба - Джибути, Белград - Будапешт, Куала-Лумпур - Сингапур, Москва - Казань и др.).

Важную роль играет модернизация трансграничной инфраструктуры, актуальная для развития периферийных регионов [20]. В частности, на российско-китайской границе идет строительство мостов через Амур между городами Благовещенск и Хэйхэ, Нижнеленинское и Тунцзян, а также мостового погранперехода Полтавка - Дуннин.

«Инфраструктурное» направление ОПОП направлено на увеличение портфеля заказов китайских строительных корпораций и их дальнейшее закрепление на рынках развивающихся стран через связанные кредиты смежным компаниям. Развитие инфраструктуры в этих странах также облегчает перенос туда производства китайских фирм и последующую работу китайских специалистов. Запуск трансевроазиатских маршрутов для Китая является одним из способов снизить транспортные расходы и тем самым поддержать конкурентоспособность китайских то-

\footnotetext{
${ }_{21}^{21}$ Чжуноу баньле цзяньшэ фачжань гуйхуа (2016-2020 гг.) [План развития CRExpress на 2016-2020 гг.]. Государственный комитет КНР по реформе и развитию // Официальный сайт ОПОП - 2016. 24 октября - URL: https://www.yidaiyilu.gov.cn/ yw/qwfb/4802.htm
} 
варов на рынках стран ЕС и ЕАЭС, а также попыткой хотя бы в небольшой степени диверсифицировать каналы поставок и придать импульс развитию приграничных районов.

\section{ГУМАНИТАРНОЕ НАПРАВАЕНИЕ}

Выход в центр мировой экономической системы нуждается в соответствующем росте культурного влияния. Китай применяет широкий спектр ресурсов наращивания «мягкой силы с китайской спецификой» [3]. В их число входит подготовка зарубежных специалистов со знанием китайского языка, предоставление гуманитарной помощи и содействие развитию (developmental aid) зарубежных стран, участие в миротворческих операциях ООН и др.

За 2005-2014 гг. в два раза увеличилось число принимающих иностранцев китайских высших учебных заведений и утроилось число иностранных учащихся, благодаря чему Китай вышел на третье место в мире по этому показателю после США и Великобритании. В 2017 г. в 935 китайских ВУЗах прошли обучение 490 тыс. иностранцев, три четверти которых приехали из стран полупериферии и периферии. Десятки тысяч иностранцев ежегодно обучаются полностью бесплатно за счет стипендии правительства КНР (в 2017 г. - 58 тыс.), значительное число (точной статистики нет) - бесплатно за счет провинциальных или городских стипендий. Распространены стажировки и курсы повышения квалификации иностранных научно-педагогических работников и преподавателей китайского языка. На конец 2017 г. в мире функционировало 525 Институтов Конфуция (в высших учебных заведениях) и 1113 классов Конфуция (в школах), где ежегодно обучается более 5 млн слушателей. Китай также финансово поддерживает образование на китайском языке для проживающих за рубежом этнических китайцев и их потомков, 304 таких учебных заведения действует в более чем 50 странах мира. Показателем роста популярности изучения китайского языка в мире является число желающих сдать государственный аттестационный тест на владение китайским языком для иностранцев (HSK, требуется при поступлении в китайские университеты, проводится в 130 странах). В 2017 г. в нем приняло участие более 6,5 млн экзаменующихся, что на 8 \% больше, чем годом ранее 22

Укрепляется взаимодействие между китайскими и зарубежными научными, творческими, медицинскими (в том числе по линии традиционной медицины) организациями. В частности, в ноябре 2016 г. в Пекине состоялось совещание Академий наук стран «Пояса и пути», направленное на выработку совместной программы исследований ${ }^{23}$. Быстро растет не только число расположенных при иностранных ВУЗах Институтов Конфуция, но и самостоятельных Китайских культурных центров. В середине 2017 г. за рубежом функционировало 30 таких центров, а к 2020 г. их число должно вырасти до $49^{24}$.

Для расширения зарубежного информационного присутствия КНР инвестирует значительные средства в вещательную сеть. Ведущее свою историю ещё с социалистических времен китайское иновещание с 2018 г. работает под единым названием «Голос Китая» (Voice of China). Его задачами являются создание альтернативной информационной повестки в части взаимодействия Китая с миром, оппонирование теории «Китайской угрозы» и создание позитивного образа китайских проектов у международной аудитории ${ }^{25}$.

Для закрепления статуса «ответственной державы», которая защищает право жителей других стран на развитие, Китай предоставляет гуманитарную помощь и помогает развитию отстающих стран. Например, Китай по своей инициативе обнулил 97 \% всех торговых пошлин для товаров из 36 наименее развитых стран. По собственным оценкам, в 1949-2016 гг. Китай оказал

\footnotetext{
${ }^{22}$ Цзяоюйбу изюйсин 2017 нянь Чжунго юйянь вэньизы шие фачжань чжуанкуан фабухуэй [Министерство образования провело пресс-конференцию, посвященную вопросам языка и письменности в Китае] // Официальный сайт Пресс-канцелярии Госсовета KHP. - 2018. 29 мая. - URL: http://www.scio.gov.cn/xwfbh/gbwxwfbh/xwfbh/jyb/Document/1630260/1630260. htm

${ }^{23}$ Шоу изе «и дай и лу» гоцзи кэцзи гаофэн луньтан изй изин чжаокай [В Пекине открылся первый Научно-технический форум «Одного пояса и одного пути»] // Официальные сайт Государственного комитета по реформе и развитию. - 2016. 8 ноября. - URL: http://www.ndrc.gov.cn/gzdt/201611/t20161108_825904.html

${ }^{24}$ Госиньбань цзюйсин «и дай и лу» яньсянь гоцзя миньсинь сянтун цинкуан фабухуэй [В Пресс-канцелярии Госсовета КНР состоялась пресс-конференция, посвященная развитию связей между народами стран «Пояса и пути»] // Официальный сайт Госсовета KHP. 11.05.2017. - URL: http://www.scio.gov.cn/xwfbh/xwbfbh/wqfbh/35861/36653/wz36655/ Document/1551339/1551339.htm

${ }^{25}$ World Needs a Better Understanding of China, "Voice of China" Can Help // Жэньминван [Интернет-сайт ИА «Жэньминь жибао»]. - 2018. 22 марта. - URL: http://en.people.cn/n3/2018/0322/c90000-9440715.html
} 
зарубежным странам помощь на общую сумму 400 млрд юаней и подготовил 12 млн специалистов $^{26}$. В 2018-2020 гг. объем помощи оценивается в 9 млрд долл. США.

Китай неизменно подчеркивает, что сам до сих пор борется с экономическими проблемами. В силу этого его помощь «носит комплексный характер и обусловлена стремлением содействовать как социально-экономическому развитию стран-реципиентов, так и реализации собственных интересов в сфере экономики и политики», в частности получению доступа к минеральных ресурсам и рынкам сбыта и загрузке китайских промышленных мощностей [5, с. 206]. Такой «горизонтальный» подход с пониманием воспринимается слаборазвитыми государствами и позволяет преодолевать ограничения традиционной модели международной помощи [25].

Показательным направлением помощи развитию является строительство на безвозмездной основе административных и общественных зданий для развивающихся стран и международных организаций. Крупнейшим проектом такого рода является строительство штаб-квартиры Африканского союза в Аддис-Абебе (Эфиопия), завершенное в 2012 г. В 2018 г. подписан меморандум о строительство за китайский счет штаб-квартиры ЭКОВАС (Экономическое сообщество западноафриканских государств) в Абудже (Нигерия). По данным СМИ, за счет китайской помощи возведены здания парламентов в Зимбабве, Конго, Малави, Гвинее-Бисау, Лесото и Габоне, президентского дворца в Кабо-Верде, Национального торгово-выставочного центра в Лаосе и др. В Сенегале за счет китайской дотации строятся монументальный Музей черных цивилизаций и Большой национальный театр, в Камбодже - Национальный стадион.

Увеличение расходов на международную помощь в последние годы приносит свои плоды. Согласно оценкам исследовательской организации AidData, за 2014-2017 гг. Китай поднялся на 8 мест в рейтинге наиболее влиятельных международных доноров (21-е место) [22]. Однако оценка «полезности» Китая в глазах получателей помощи оставалась невысокой (31-е место) в основном из-за несогласованности различных каналов предоставления помощи. Ситуация может быстро улучшиться после создания в 2018 г. Государственного агентства по сотрудничеству в области международного развития в прямом подчинении Госсовета КНР. Его функционал включает в себя разработку и проведение единой стратегии зарубежной гуманитарной помощи, контроль и координацию ведомств-исполнителей.

Важным способом продемонстрировать свой вклад в решение международных проблем является участие в миротворческих операциях ООН. Миротворческий контингент Китая (2,5 тыс. человек) в конце 2017 г. численно превышал контингенты других членов Совбеза ООН, хотя и уступал ряду развивающихся стран. Помимо увеличения численности своего контингента и числа наблюдателей, Китай делает финансовые взносы на миротворческую деятельность. На период 2016-2018 гг. он пожертвовав 810 млн долл. - это 10,3\% всех взносов - второе место после США [8].

Таким образом, курс на укрепление близости между народами включает в себя подготовку кадрового резерва из числа своих и зарубежных граждан для осуществления зарубежных проектов китайских ТНК, а также последовательную работу с общественным мнением для купирования опасений по поводу экспансионистских намерений Китая, продвижение позитивного имиджа, «мягкой силы». Уже сейчас, по данным социологов, жители развивающихся стран лучше жителей развитых оценивают Китай и ОПОП, более положительно относятся к китайской модели ${ }^{27}$.

Несмотря на распространенное мнение, главное содержание китайского мега-проекта «Один пояс, один путь» значительно шире развития трансконтинентальных логистических маршрутов и фактически включает в себя комплексное содействие коммерческой деятельности китайских компаний на зарубежных рынках. Анализ закрепленных в официальных документах положений и практики госполитики свидетельствует, что пять «интеграционных направлений» ОПОП являются теми «рельсами», по которым Китай движется к центру «мировой сцены». Конкрет-

\footnotetext{
${ }^{26}$ Фачжаньцюань: Чжунго дэ линянь, шицзянь юй гунсянь [Право на развитие: теория, практика и вклад Китая] // Официальный сайт Пресс-канцелярии Госсовета KHP. - 2016. 1 декабря. - URL: http://www.gov.cn/zhengce/2016-12/01/ content_5141177.htm

27 Доклад о государственном имидже Китая // Китай. - 2018. - № 3. - С. 12-13.
} 
нее, это пять аспектов поддержки своих корпораций в их движении вверх по цепочкам добавленной стоимости ради вхождения экономики страны в центр мирового хозяйства.

Резюмируя анализ, можно кратко сформулировать ключевые моменты пяти направлений внешнеэкономического курса «Один пояс, один путь». Путем внешнеполитического согласования (1) Китай выводит коммерческие проекты на межгосударственный уровень, что упрощает работу в странах со сложным деловым климатом, а также участвует в разработке отраслевой и территориальной политики государств-партнеров. В сфере международных финансов (2) Китай стремится повысить интернационализацию юаня и выстроить альтернативную систему международных финансовых институтов для увеличения преимуществ домашних компаний при реализации зарубежных проектов. В сфере инфраструктуры (3) Китай работает на расширение рынка заказов для своих строительно-подрядных корпораций, а также старается снизить себестоимость доставки производимой в Китае продукции на зарубежные рынки. Торгово-инвестиционная интеграция (4) направлена на борьбу с торговыми барьерами, облегчение экспорта капитала и производственных мощностей, в том числе в форме совместных промышленных парков. Гуманитарная «мягкая сила» (5) призвана облегчать реализацию зарубежных коммерческих проектов, для чего Китай инвестирует в обучение иностранцев, увеличивает свой «полезный вклад» в международные дела (гуманитарная помощь, миротворческая деятельность и др.), развивает иновещание и пр.

Проанализированные меры укладываются в довольно стройную картину усилий по обеспечению бесконфликтного расширения присутствия китайских частных и государственных компаний за рубежом. Арена действий - периферия и полупериферия мирового хозяйства («страны “Пояса и пути”», в первую очередь Юго-Восточная Азия, Африка, Средний и Ближний Восток, Средняя Азия), где Китай с помощью финансовых и политических рычагов теснит компании из развитых стран. Нельзя игнорировать и внутриполитическую мотивацию внешнеэкономических мер: самостоятельную значимость для народа и руководства имеет укрепление статуса Китая в глазах международного сообщества и формирование имиджа великой державы.

Ещё недавно господствовало мнение, согласно которому Китай неохотно берет на себя лидерство в международных вопросах, а китайский народ не одобряет зарубежные инициативы правительства (см., например, [26]). Однако с тех пор появились признаки отхода Китая от курса на «нераспространение» своей экономической модели. В последние годы в Китае на разных уровнях заявляется о полезности передачи опыта экономического строительства развивающимся странам ${ }^{28}$. Позиция «мудреца» в китайском мировоззрении находится не ниже позиции «правителя», а знание ценится больше, чем власть, что обеспечивает широкую поддержку такого подхода к международной политике среди граждан. Китай видит в развивающихся странах себя в недалеком прошлом, и цель государства - направить ресурсы китайских предприятий туда, где они имеют больше опыта и перспектив.

За четыре десятилетия с начала реформ Китай кардинально изменился и продолжает меняться. Завершается фундаментальный переход от планового хозяйства с доминированием государственной и коллективной собственности к многоукладной экономике на рыночных принципах. Уже фактически состоялся отраслевой переход от аграрно-индустриальной к индустриально-сервисной структуре занятости с растущей долей технических инноваций. «Один пояс, один путь», будучи новым, закономерным этапом политики открытости, направлен на реализацию следующего внешнеэкономического перехода - от импорта инвестиций и капитала к его экспорту, от объекта к субъекту глобальной экономики. «Фабрика мира» выходит «в мир», и в этом смысле ОПОП является полноценным «локомотивом включения развивающихся стран в международное разделение труда» [6, с. 5] и трансформации международного разделения труда, конечная успешность которого, при всем этом, неочевидна [4]. Для подлинно взаимовыгодного сотрудничества китайским компаниям предстоит научиться гармонично сочетать достоинства национальной системы менеджмента и опыт работы на внутреннем рынке с требованиями и интересами стран-партнеров.

\footnotetext{
${ }^{28}$ Примером может служить выступление заместителя председателя КНР Ван Цишаня на 3-ем Китайско-африканском форуме сотрудничества региональных администраций в мае 2017 г. См: China’s Know-how to Aid Africa // China Daily, May 9, 2018. - URL: http://europe.chinadaily.com.cn/a/201805/09/WS5af2372fa3105cdcf651cbf4.html
} 


\section{АИТЕРАТУРА}

1. Бергер Я. М. Экономическая стратегия Китая. - М.: Форум, 2009. - 560 с.

2. Гельбрас В. Г. Экономика Китайской Народной Республики. - М.: Квадрига, 2010. - 642 с.

3. Жигарьков Г. А. «Мягкая сила» с китайской спецификой: конкуренция за общественное мнение // Международная жизнь. - 2018. - № 6. - С. 48-61.

4. Калашников Д. Б. Трансформация мирового хозяйства под воздействием экономического развития Китая // Мировое и национальное хозяйство [Электронный журнал МГИМО МИД России]. - 2017. - № 4. URL: http://www.mirec.ru/2017-04/the-rise-of-china-and-its-impact-on-the-evolution-of-the-world-economy

5. Кашин В. Б., Королев А. С., Пятачкова А. С. Китайская политика помощи зарубежным странам: основные принципы и направления // Китай в мировой и региональной политике. История и современность. - М.: ИДВ РАН, 2017. - Вып. 22. - С. 204-218.

6. Колосов В. А., Гречко Е. А., Мироненко К. В., Самбурова Е. Н., Слука Н. А., Тикунова И. Н., Ткаченко Т. Х., Федорченко А. В., Фомичев П. Ю. Горизонты исследований в области географии мирового хозяйства // Вестник Московского университета. Серия 5: География. - 2016. - № 1. - С. 3-12.

7. Кондрашова Л. И. Китай: к новой модели общественного развития. - М.: Форум, 2017. - 336 с.

8. Лексютина Я. В. Вклад современного Китая в миротворческую деятельность ООН / Под ред. А. И. Кобзева // Общество и государство в Китае. Т. XLVIII. Ч. 1 - М.: ИВ РАН, 2018. - С. 305-311.

9. Лексютина Я. В. Китай и реформирование международной экономической системы // Сравнительная политика. - 2018. - № 3. - С. 26-41.

10. Лексютина Я. В. Функциональные изменения участия Китая в многосторонних банках развития: от заемщика к кредитору // Вестник международных организаций. - 2018. - T. 13. - № 1. - C. 80-98. - DOI: 10.17323/1996-7845-2018-01-05

11. Лузянин С. Г., Афонасьева А. В. Один пояс, один путь - политические и экономические измерения // Вестник Томского государственного университета. Экономика. - 2017. - № 40. - С. 5-14.

12. Лю Вэйдун. «Идай и лу»: иньлин баожунсин цюаньцюхуа [«Один пояс, один путь»: направляя инклюзивную глобализацию]. - Пекин: Шан’у иншугуань, 2017. - 195 с.

13. Портяков В. Я. Становление Китая как ответственной глобальной державы. - М.: ИДВ РАН, 2013. - 240 с.

14. Прекрасные перспективы и практические действия по совместному созданию Экономического пояса Шелкового пути и Морского Шелкового пути 21 века. - Пекин: Изд-во литературы на ин. языках, 2017. $45 \mathrm{c}$.

15. Самбурова E. H., Мироненко K. В. Китай в мировом хозяйстве: пути взаимодействия / Под ред. Л. М. Синцерова // География мирового хозяйства: сборник научных трудов. - М.: Товарищество научных изданий КМК, 2016. - Вып. 3. - С. 422-434.

16. Совместное строительство «Одного пояса, одного пути»: идея, практика и вклад Китая. - Пекин: Изд-во литературы на ин. языках, 2017. - 75 с.

17. Титаренко М. Л., Ломанов А. В. Политические и культурные аспекты стратегии становления Китая как великой державы // Проблемы Дальнего Востока. - 2015. - № 3. - С. 17-27.

18. Чубаров И. Г. География сопряжения: региональная политика КНР и пространственное развитие стран ЕАЭС // Проблемы Дальнего Востока. - 2017. - № 5. - С. 114-125.

19. Чубаров И. Г., Калашников Д. Б. «Один пояс - один путь»: глобализация по-китайски // Мировая экономика и международные отношения. - 2018. - № 1. - С. 25-33.

20. Чубаров И. Г., Михайлова Е. В. Проблемы преодоления периферийности российско-китайского трансграничья // Россия в АТР. - 2017. - № 4. - С. 88-105.

21. Chinese Brands Go Global: China Trademark Report / CompuMark. - 2018. - 65 p.

22. Custer S., DiLorenzo M., Masaki T., Sethi T., Harutyunyan A. Listening to Leaders 2018: Is Development Cooperation Tuned-in or Tone-deaf? - Williamsburg, VA: AidData at the College of William \& Mary, 2018.

23. Hu Binliang. China’s Key to Success // China Today. - 2017. - № 12. - P. 25-30.

24. Kolosov V. A., Suocheng D., Portyakov V. Y., Chubarov I. G., Tarkhov S. A., Shuper V. A. The Chinese Initiative "The Belt and Road": a Geographical Perspective // Geography, Environment, Sustainability. - 2017. - № 10. - P. 5-20. DOI: $10.24057 / 2071-9388-2017-10-1-5-20$

25. Ngangom T. The Sharp Power of Development Diplomacy and China's Edge // Observer Research Foundation, March 11, 2018. - URL: https://www.orfonline.org/expert-speaks/sharp-power-development-diplomacy-china-edge/

26. Stiglitz J. E. The Chinese Century // Vanity Fair, January 2015. - URL: https://www.vanityfair.com/news/2015/01/ china-worlds-largest-economy 


\title{
ILYA CHUBAROV
}

\section{Five Connectivity Areas of the China's Belt and Road Initiative}

\author{
Ilya Chubarov, PhD (Human Geography), Senior Research Fellow, \\ Institute of the Far Eastern Studies, Russian Academy of Sciences. \\ E-mail: ilya.chubarov@gmail.com
}

\begin{abstract}
Summary. The article strives to go beyond the common understanding of China's BRI strategy as a set of Eurasian logistics corridors and related investment and transportation projects. Scrutinizing the five integration areas (wu tong), namely foreign policy, infrastructure, trade \& economic, financial and humanitarian, one can come to the conclusion that it is a set of activities to support the "going out" of the Chinese commercial firms to the leading positions in various sectors of the world economy. Climbing up the value chain by the "national champions" is a necessary condition for China's entrance to the center of the world economy. The arena of action is the periphery and semi-periphery (so called "countries along the belt and road"), where China is gradually pushing out corporations of developed countries. In addition, the strengthening of China's status in the eyes of the international community and the formation of the image of a great power hold independent importance for the people and leadership. Assessing BRI as the next natural stage of China's foreign economic openness policy at the new stage of globalization and at the same time as a self-valuable tool for restoring the country's prestige on the world stage allows more accurate evaluate Chinese intentions in joint projects.
\end{abstract}

Keywords: China, BRI, globalization.

\section{REFERENCES}

Berger Ya. M. Ekonomicheskaya strategiya Kitaya [Economic Strategy of China]. - Moscow: Forum, 2009. - 560 p.

Building the Belt and Road: Concept, Practice and China's Contribution. May 10, 2017. URL: https://eng.yidaiyilu.gov.cn/ zchj/qwfb/12731.htm

Chinese Brands Go Global: China Trademark Report. CompuMark, 2018. 65 p.

Chubarov I. G. Geografiya sopryazheniya: regional'naya politika KNR i prostranstvennoe razvitie stran EAES [Geography of Conjunction: Regional Policy of the PRC and Spatial Development of the EAEU Countries]. Problemy Dal'nego Vostoka. 2017. No. 5. P. 114-125.

Chubarov I. G., Kalashnikov D. B. "Odin poyas - odin put": globalizatsiya po-kitaiski [Belt and Road Initiative: Globalization Chinese Way?] // Mirovaya ekonomika i mezhdunarodnye otnosheniya. 2018. No. 1. P. 25-33.

Chubarov I. G., Mikhailova E. V. Problemy preodoleniya periferiinosti rossiisko-kitaiskogo transgranich'ya [Overcoming the Periphery: Sino-Russian Borderland]. Rossiya v ATR. 2017. No. 4. P. 88-105.

Custer S., DiLorenzo M., Masaki T., Sethi T., and A. Harutyunyan. Listening to Leaders 2018: Is Development Cooperation Tuned-in or Tone-deaf? Williamsburg, VA: AidData at the College of William \& Mary, 2018.

Gel'bras V. G. Ekonomika Kitaiskoi Narodnoi Respubliki [PRC: National Economy]. Moscow: Kvadriga, 2010. 642 p.

Hu Binliang. China's Key to Success. China Today. 2017. No. 12. P. 25-30.

Kalashnikov D. B. Transformatsiya mirovogo khozyaistva pod vozdeistviem ekonomicheskogo razvitiya Kitaya [The Rise of China and Its Impact on the Evolution of the World Economy]. Mirovoe i natsional'noe khozyaistvo. 2017. No. 4. - URL: http://www.mirec.ru/

Kashin V. B., Korolev A. S., Pyatachkova A. S. Kitaiskaya politika pomoshchi zarubezhnym stranam: osnovnye printsipy i napravleniya [Chinese Foreign Aid: Main Principles and Directions]. Kitai v mirovoi i regional'noi politike: istoriya i sovremennost'. Issue 22. Moscow: Institute of Far Eastern Studies of the Russian Academy of Sciences, 2017. P. 204-218. 
Kolosov V. A., Suocheng D., Portyakov V. Y., Chubarov I. G., Tarkhov S. A., Shuper V. A. The Chinese Initiative "The Belt and Road": a Geographical Perspective. Geography, Environment, Sustainability. 2017. No. 10. P. 5-20. DOI: $10.24057 / 2071-9388-2017-10-1-5-20$

Kolosov V. A., Grechko E. A., Mironenko K. V., Samburova E. N., Sluka N. A., Tikunova I. N., Tkachenko T. Kh., Fedorchenko A. V., Fomichev P. Yu. Gorizonty issledovanii v oblasti geografii mirovogo khozyaistva [Horizons of Research in the Geography of World Economy]. Vestnik Moskovskogo universiteta. Seriya 5: Geografiya. 2016. No. 1. P. 3-12.

Kondrashova L. I. Kitai: $k$ novoi modeli obshchestvennogo razvitiya [China: Towards the New Model of Social Development]. Moscow: Forum, 2017. 336 p.

Leksyutina Ya. V. Vklad sovremennogo Kitaya v mirotvorcheskuyu deyatel'nost' OON. [Chinese Contribution to the UN Peacekeeping Activities]. Obshchestvo i gosudarstvo v Kitae. Vol. XLVIII, Part .1. Moscow: Institute of Oriental Studies of the Russian Academy of Sciences, 2018. P. 305-311.

Leksyutina Ya. V. Kitai i reformirovanie mezhdunarodnoi ekonomicheskoi sistemy [China and Remaking of the International Economic System]. Sravnitel'naya politika. 2018. No. 3. P. 26-41.

Leksyutina Ya. V. Funktsional'nye izmeneniya uchastiya Kitaya v mnogostoronnikh bankakh razvitiya: ot zaemshchika k kreditoru [Functional Changes in Chinese Participation in the Multilaterial Development Banks: from the Debtor to the Creditor]. Vestnik mezhdunarodnykh organizatsii. 2018. Vol. 13. No. 1. P. 80-98. DOI: 10.17323/1996-7845-201801-05

Liu Weidong. Yi dai yi lu: yinling baorongxing quanqiuhua [One Belt, One Road: Leading the Inclusive Globalization]. Beijing: Commercial Press, 2017. 195 p.

Luzyanin S. G., Afonas'eva A. V. Odin poyas, odin put' - politicheskie i ekonomicheskie izmereniya [One Belt, One Road: Political and Economic Dimensions]. Vestnik Tomskogo gosudarstvennogo universiteta. Ekonomika. 2017. No. 40. P. 5-14.

Ngangom T. The Sharp Power of Development Diplomacy and China's Edge. Observer Research Foundation, March 11, 2018. - URL: https://www.orfonline.org/expert-speaks/sharp-power-development-diplomacy-china-edge/

Portyakov V. Ya. Stanovlenie Kitaya kak otvetstvennoi global'noi derzhavy [The Formation of China as a Responsible Global Power]. M.: Institute of Far Eastern Studies of the Russian Academy of Sciences, 2013. 240 p.

Samburova E. N., Mironenko K. V. Kitai v mirovom khozyaistve: puti vzaimodeistviya [China in the World Economy: Ways of Interaction]. Geografiya mirovogo razvitiya. Issue 3. Moscow, 2016. P. 422-434.

Stiglitz J. E. The Chinese Century. Vanity Fair. January 2015. URL: https://www.vanityfair.com/news/2015/01/china-worlds-largest-economy

Titarenko M. L., Lomanov A. V. Politicheskie i kul'turnye aspekty strategii stanovleniya Kitaya kak velikoi derzhavy [Political and Cultural Aspects of Strategy of Formation China as a Great Power]. Problemy Dal'nego Vostoka. 2015. No. 3. P. 17-27.

Vision and Actions on Jointly Building Silk Road Economic Belt and 21st-Century Maritime Silk Road. March 28, 2015. URL: http://en.ndrc.gov.cn/newsrelease/201503/t20150330_669367.html

Zhigar'kov G. A. «Myagkaya sila» s kitaiskoi spetsifikoi: konkurentsiya za obshchestvennoe mnenie ["Soft Power" with Chinese Characteristics: Competing for the Public Opinion]. Mezhdunarodnaya zhizn’. 2018. No. 6. P. $48-61$. 